\title{
SPRAYING SYSTEMS AND TRAVELING SPEED IN THE DEPOSIT AND SPECTRUM OF DROPLETS IN COTTON PLANT
}

Doi:http://dx.doi.org/10.1590/1 809-4430-Eng.Agric.v35n6p 1042-1052/2015

\section{JHONATAN D. CAVALIERI ${ }^{1}$, CARLOS G. RAETANO ${ }^{2}$, RONALDO P. MADUREIRA ${ }^{3}$, LAIS L. Q. MOREIRA ${ }^{4}$}

\begin{abstract}
Tractor traveling speed can influence the quality of spraying depending on the application technology used. This study aimed to evaluate the droplet spectrum, the deposition and uniformity of spray distribution with different spraying systems and traveling speeds of a selfpropelled sprayer in two phenological stages of the cotton plant (B9 and F13). The experimental design was randomized blocks and treatments were three spraying techniques: common flat spray tips; tilted flat jet with air induction, at $120 \mathrm{~L} \mathrm{ha}^{-1}$; and rotary atomizer disk, $20 \mathrm{~L} \mathrm{ha}^{-1}$, combined with four traveling speeds: 12, 15, 18 and $25 \mathrm{~km} \mathrm{~h}^{-1}$, with four replications. Spraying deposition was evaluated for both leaf surfaces from the cotton plant apex and base (stage B9) and middle part of the plant (stage F13) with a cupric marker. A laser particle analyzer also assessed the droplet spectrum. The centrifugal power spray system produces more homogeneous droplet spectrum and increased penetration of droplets into the canopy in both phenological stages. Variation on the operating conditions necessary for increased traveling speed negatively influences the pattern of spraying deposits.
\end{abstract}

KEYWORDS: application technology, rotary atomizer disk, rotating nozzle, Gossypium hirsutum L.

\section{SISTEMAS DE PULVERIZAÇÃO E VELOCIDADE DE DESLOCAMENTO NO DEPÓSITO E ESPECTRO DE GOTAS EM ALGODOEIRO}

\begin{abstract}
RESUMO: A velocidade de deslocamento pode influenciar na qualidade da pulverização em função da tecnologia de aplicação utilizada. O trabalho teve como objetivo avaliar o espectro de gotas, a deposição e a uniformidade de distribuição da pulverização com diferentes sistemas de pulverização, e a velocidades de deslocamento de um pulverizador autopropelido, em dois estádios fenológicos do algodoeiro (B9 e F13). O delineamento experimental foi o de blocos ao acaso, e os tratamentos foram três técnicas de pulverização: pontas de jato plano comum; jato plano inclinado com indução de ar, a $120 \mathrm{~L} \mathrm{ha}^{-1}$; e atomizador rotativo de disco, a $20 \mathrm{~L} \mathrm{ha}^{-1}$, combinados a quatro velocidades de deslocamento: $12 ; 15 ; 18$ e $25 \mathrm{~km} \mathrm{~h}^{-1}$, em quatro repetições. A deposição da pulverização foi avaliada em ambas as superfícies foliares do ápice e da base do algodoeiro (estádio B9) e a parte média da planta (estádio F13), com um marcador cúprico. Também foi avaliado o espectro de gotas por um analisador de partículas a laser. O sistema de pulverização de energia centrífuga produz espectro de gotas mais homogêneo e maior penetração das gotas no dossel, em ambos os estádios fenológicos. A variação nas condições operacionais necessárias para o aumento da velocidade de deslocamento influencia negativamente sobre o padrão dos depósitos da pulverização.
\end{abstract}

PALAVRAS-CHAVE: Tecnologia de aplicação, atomizador rotativo de disco, bico rotativo, Gossypium hirsutum L.

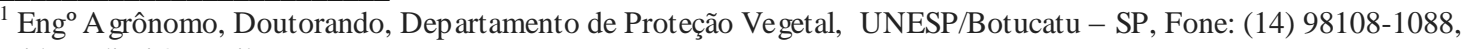
jdcavalieri@gmail.com

2 Eng ${ }^{\circ}$ A grônomo, Prof. Doutor, Departamento de Proteção Vegetal, UNESP/Botucatu - SP, raetano@fca.unesp.br

${ }^{3}$ Eng $^{\circ}$ A grônomo, Doutorando, Departamento de Engenharia A grícola, UFV/Viçosa - MG, ronaldomadureira22@y ahoo.com.br

${ }^{4}$ Eng $^{\circ}$ A grônomo, Prof.-Mestre, Departamento de Agronomia, IFNMG/Januária MG, moreira.lais@ ifnmg.edu.br

Recebido pelo Conselho Editorial em: 03-2-2015
}

Aprovado pelo Conselho Editorial em: 22-6-2015 


\section{INTRODUCTION}

Cotton plants (Gossypium hirsutum L.) present a number of problems related to crop protection, among which is the presence of several species of phytophagous insects, which would cause yield and fiber quality losses from emergence to maturity (SANTOS, 2011). As a result, around 30 sprayings are held throughout the crop cycle, which corresponds to $25 \%$ of production costs (AGRIANUAL, 2013). Therefore, to minimize phytosanitary problems, it becomes necessary to adopt practices that are efficient and allow for increasing sustainability in cotton production.

The intensification of farming in areas of great agricultural extension and the adoption of crop succession practices have favored the increase in the population pressure of several polyphagous insect species. Among those, the Helicoverpa armigera (CZEPAK et al., 2013) stands out, leading to increased use of chemical control. Allied to this, there is the need for spraying to be carried out within short intervals for satisfactory control of these insect pests (WOLF \& DAGGUPATI, 2009).

In order to meet this demand, farmers have adopted practices such as reduced application rates and increased sprayer-traveling speeds, seeking to increase the operational capacity of machines. However, the changes in these factors and in the operating conditions, associated with the application technology, can negatively influence the levels of spraying deposits and increase drift losses mainly associated to medium and fine droplets (HEIDARY et al., 2014), which may result in lower phytosanitary treatment efficiency and increased environmental impact.

It is essential to ensure uniformity in spraying distribution and coverage of the target in applications, in order to maximize the biological efficiency of the phytosanitary treatment. This is particularly important for the pest species which affect the inner parts of the plant canopy, where contact with chemicals in sprays with hydraulic tips is hindered (BAYER et al., 2012). In addition, the low capacity of redistribution of crop protection products must be considered, especially fungicides and insecticides, characterizing the importance of the appropriate choice of application technology.

Nowadays, the market offers constructive technologies that offer advantages, such as uniform control of droplets provided by CDA technology (Controlled Drop Application), reducing losses by very small drops, which are prone to drifting and evaporation, as well as very large ones, susceptible to draining (DI OLIVEIRA et al., 2010), enabling better deposit uniformity and biological efficiency. Other technologies have considerable reduction of fine droplets in response to induction/insertion of air inside the drops. Hydraulic tips with air induction allow greater spreading capacity of the liquid by the impact of droplets on the surface and may result in greater target coverage (BOLLER \& RAETANO, 2011). Both technologies can be effective in reducing the spraying volume at higher travel speeds, ensuring the effectiveness of chemical control, making it possible to reduce the application rate and maximizing the operational capability of the machines, as well as reducing the risk of environmental contamination.

This work aimed to evaluate the spectrum of spraying droplets, the deposition and uniformity of the spray mixture distribution produced by hydropower tips and centrifugal energy spray system under different traveling speeds of a self-propelled sprayer in two phenological stages of the cotton plant.

\section{MATERIAL AND METHODS}

\section{Spraying deposit}

Two experiments were conducted on cotton, G. hirsutum L., during the crop season of 2012/2013, in Paranapanema, SP. The experimental area had flat topography, no presence of terraces, situated 600 meters above sea level, with the following geographical coordinates: latitude $22^{\circ} 37^{\prime} 59^{\prime \prime} \mathrm{S}$ and longitude $47^{\circ} 03^{\prime} 20^{\prime \prime} \mathrm{O}$. On October 30, 2012, the direct sowing of cultivar FIBERMAX FM 910 was carried out, with a density of ten plants per meter and $0.96 \mathrm{~m}$ spacing between rows. The soil of the experimental area was classified as clayey Red Latosol (Oxisol). 
Experiment I was conducted at phenological stage B9 (74 days after sowing - DAS) and experiment II at stage F13 (117 DAS), according to the phenological scale proposed by MARUR \& RUANO (2001). These periods correspond to the pre and post-closing of the spacing in cotton crops. At each development stage, the leaf area index (LAI) and plant height were measured. In order to do so, twenty-four plants were collected in each block (two plants per plot), their leaves were removed and the total leaf area was measured with the aid of a measuring table leaf area meter (LICOR, model 3100), relating leaf area of plants per unit of soil area. The experimental design for both experiments was randomized blocks and treatments were organized in factorial $3 \times 4$ (three spray techniques combined with four traveling speeds), in four replications, as specified in Table 1. The experimental unit was sized $12 \times 30 \mathrm{~m}$ (width x length) where $12 \mathrm{~m}$ corresponds to $50 \%$ of the spray bar size and $30 \mathrm{~m}$ to the plot length. The service area for sample collection was $8 \mathrm{~m} \times 10 \mathrm{~m}$ $\left(80 \mathrm{~m}^{2}\right)$, in the central part of the plot and the rest of the area was considered curbstone. The spraying was carried out covering the entire plot and with movement starting $30 \mathrm{~m}$ away before the portion to be sprayed (plot splitter) in order to achieve stability in the sprayer traveling speed.

A self-propelled Jacto sprayer (Pompeia/SP) was used, Uniport model, serial number 504496, tank capacity of $2000 \mathrm{~L}$ and a $24 \mathrm{~m}$ long bar. The spraying was carried out towards the sowing ranks of the cotton plants, triggering only half the spray bar with 24 hydraulic tips or 8 centrifugal power tips. The spacing used between the hydraulic tips was $0.5 \mathrm{~m}$, while the centrifugal energy tips were spaced at $1.35 \mathrm{~m}$. The respective operating conditions are described in Table 1 . At the time of application, the bar was maintained at $0.50 \mathrm{~m}$ height above the canopy apex. Traveling speeds were previously monitored using an embedded electronic controller, MF 2000 JSC model, serial number 30914. The pressure range adopted in spraying with hydraulic tips (flat jet Jacto AXI and tip with air induction by Hypro GA) was selected for the generation of medium-sized droplets, as specified in the manufacturers' catalog (JACTO, 2012; HYPRO, 2015). During spraying, pressures were monitored in the controller and values adjusted in the pressure controller, certified by the pressure gauge. The application rate was $120 \mathrm{~L} \mathrm{ha}^{-1}$ for both hydraulic energy tips.

TABLE 1. Specifications of treatments and operational conditions in spraying.

\begin{tabular}{llllll}
\hline Technology & $\begin{array}{l}{ }^{(1)} \text { Combination } \\
\text { Tip/nozzle }\end{array}$ & $\begin{array}{l}\text { Spraying } \\
\text { Technique }\end{array}$ & $\begin{array}{l}\text { Speed } \\
\left(\mathrm{km} \mathrm{h}^{-1}\right)\end{array}$ & $\begin{array}{l}\text { Pressure } \\
(\mathrm{kPa})\end{array}$ & $\begin{array}{l}\text { Outflow } \\
\left(\mathrm{L} \mathrm{min}^{-1}\right)\end{array}$ \\
\hline T1 - ${ }^{(2)}$ TT-88B & D2-13 & ${ }^{(3)} \mathrm{EC}$ & $1(12)$ & 414 & 0.54 \\
T2 - TT-88B & D4-13 & EC & $2(15)$ & 290 & 0.68 \\
T3 - TT-88B & D2-25 & EC & $3(18)$ & 379 & 0.81 \\
T4 - TT-88B & D4-25 & EC & $4(25)$ & 345 & 1.13 \\
T5 - ${ }^{(2)}$ AXI 11003 & - & ${ }^{(3)}$ LS & $1(12)$ & 270 & 1.2 \\
T6 - AXI 11004 & - & LS & $2(15)$ & 237 & 1.5 \\
T7 - AXI 11004 & - & LS & $3(18)$ & 339 & 1.8 \\
T8 - AXI 11006 & - & LS & $4(25)$ & 446 & 2.5 \\
T9 - ${ }^{(2)}$ GA 11002 & - & ${ }^{(3)}$ LSIA & $1(12)$ & 725 & 1.2 \\
T10 - GA 110025 & - & LSIA & $2(15)$ & 707 & 1.5 \\
T11 - GA 11003 & - & LSIA & $3(18)$ & 690 & 1.8 \\
T12 - GA 11004 & - & LSIA & $4(25)$ & 770 & 2.5
\end{tabular}

(1) Combination of tip-nozzle responsible for regulating the fluid flow in the rotating nozzle ${ }^{(2)}$ TT - rotary disk atomizer; AXI and GA - hy draulic tips. ${ }^{(3)} \mathrm{EC}$ - centrifugal power sy stem; LS - simple flat jet tip; LSIA - tilted flat jet air induction. 
In treatments where the rotating nozzle model Turbo Tractor ${ }^{\circledR}$ TT-88B (CBB - Brazilian Bioaeronautics Center) was used, the application rate was $20 \mathrm{~L} \mathrm{ha}^{-1}$, with $5 \%$ of the volume corresponding to vegetable oil (NATUR'L ÓLEO ${ }^{\circledR}$ - Stoller do Brasil) and $0.5 \%$ of spreader-sticker nonylphenoxy poly ethanol (AGRAL® - Syngenta), as recommended by the manufacturer. In this system, spraying is produced by rotation of three overlapping polyethylene disks with a diameter of $0.087 \mathrm{~m}$, with grooves responsible for directing the liquid to the periphery of the disks, where droplets are generated. An electric engine connected to a speed controller, which in turn was connected to a $12 \mathrm{~V}$ battery, drives the rotation of the discs (170 A). In spraying, the controller was set to produce droplets of medium size, with disk rotation corresponding to $617.85 \mathrm{rad} \mathrm{s}^{-1}$. The angle of rotary nozzles was adjusted to $30^{\circ}$ to the vertical, in the direction of the sprayer movement. The control of the rotating nozzle flow was established by the combination of the tip - nozzle set (core), this being of the conical jet type "Disc Type TEEJET" series D.

Before spraying treatments, artificial targets made of filter-paper strips, size $0.03 \times 0.03 \mathrm{~m}$, were distributed in ten plants in each plot arranged perpendicularly to the spray movement. Four collectors were fixed in each of the 10 plants in experiment I (B9), one on its adaxial surface and the other on the abaxial surface, on the apex (last fully formed leaf located on the top of the plant) and plant base (first true leaf). In Experiment II (F13) due to the greater plant height, the collectors were also set in the middle part of the plant (whole leaf in the middle part of the plant), on both leaf surfaces. This procedure was used to assess precisely the vertical distribution of deposits within the canopy.

A cupric fungicide was used as a chemical marker, in the form of copper oxychloride (Cobox ${ }^{\circledR}$ - BASF) at a concentration of $2500 \mathrm{mg} \mathrm{L}^{-1}\left(2.5 \mathrm{~g} \mathrm{~L}^{-1}\right.$ of water), according to the method described by CHRISTOVAM et al. (2010). After the marker spraying, artificial targets were detached from plants with tweezers and fully stored in plastic bags with the dimension of $0.06 \mathrm{x}$ $0.22 \mathrm{~m}$ in sets of five filter-paper strips taken from the same position of the plant and leaf surface. Artificial targets were kept in a cooler (Styrofoam) and then taken to the laboratory where sample preparation proceeded.

The filter-paper strips were transferred to glass jars with $50 \mathrm{ml}$ capacity and the plastic bags were washed with $20 \mathrm{~mL}$ of nitric acid extraction solution $1 \mathrm{~mol} \mathrm{~L}^{-1}$, proceeding to stirring for $30 \mathrm{~s}$ aiming to extract the marker residue present in the plastic bag. The vials containing filter-paper strips were capped and taken to be stirred for 15 minutes at a speed of $23.04 \mathrm{rad} \mathrm{s}^{-1}$ in a shaker table, to better extract the marker substance. The glass jars with solutions were kept in a refrigerator $\left(8 \pm 3^{0} \mathrm{C}\right)$ for a period of $24 \mathrm{~h}$, to be then withdrawn until they reached room temperature. Subsequently, the vials were taken for reading on an atomic absorption spectrophotometer PERKIN-ELMER model 2380.

The quantification of the marker mass retained in the target was established by the same method described by CUNHA et al. (2011). The comparison of the two spraying techniques efficiency (hydraulic power and centrifuge) was performed through the standardization of the cupric marker dosage applied per area unit $\left(\mathrm{g} \mathrm{ha}^{-1}\right)$. For this, the marker mass deposited in the targets $(\mu \mathrm{g}$ $\mathrm{cm}^{-2}$ ) of the treatments which used the centrifugal energy tip with application rate of $20 \mathrm{~L} \mathrm{ha}^{-1}$ was multiplied by the correction factor $(\mathrm{CF}=6)$, this being proportional to the treatment application rate with hydraulic power tips $\left(120 \mathrm{~L} \mathrm{ha}^{-1}\right)$. This procedure was necessary for keeping the cupric marker concentration constant in the spray tank, thus preventing saturation and precipitation of the marker substance in the tank. In addition, there was an assessment of uniformity of the mixture deposit over the plant profile.

During spraying, local weather conditions were monitored with the aid of a digital thermohygro-anemometer (AM-4201), respecting the wind speed range $\left(3-10 \mathrm{~km} \mathrm{~h}^{-1}\right)$, temperature (below $30{ }^{\circ} \mathrm{C}$ ) and relative humidity $\mathrm{RH} \%(60-80 \%)$. 


\section{Spraying droplets spectrum}

Droplets were evaluated in their diameter and uniformity by means of a laser particle size measuring apparatus (Malvern Mastersizer S, version 2.19). The adjustment required for this equipment model was performed according to the method described by DI OLIVEIRA et al. (2010).

Droplet spectrum analyses were performed in the laboratory under controlled conditions: temperature of $25 \pm 3{ }^{\circ} \mathrm{C}$, relative humidity of $62 \pm 2 \%$ and no wind. The spray mixture and the treatments distribution in the laboratory evaluation were similar for deposit assessments carried out in the field, and the simulation of the factor "traveling speed" following the operating conditions (pressure and flow) of the spray systems described above (Table 1).

For each sample of the hydraulic and centrifugal spraying systems, four readings have been recorded, obtaining the average values for the following droplets spectrum parameters: volume median diameter (VMD), uniformity of the droplets spectrum (SPAN) and percentage of the volume applied with droplets with diameter smaller than $100 \mu \mathrm{m}(\% \mathrm{~V}<100 \mu \mathrm{m})$.

The data relating to droplet spectra were analyzed following the completely randomized design (CRD), and repetitions represented by four samples of hydraulic tips and rotary nozzles with respective flow regulator set (nozzle-diffuser).

In data analyses, the waste homoscedasticity was initially evaluated (Hartley and ShapiroWilk tests, $\mathrm{p}>0.05)$. Subsequently, they were subjected to variance analysis by the $\mathrm{F}$ test and, when appropriate, the means were compared by the Tukey test $(\mathrm{p}<0.05)$.

\section{RESULTS AND DISCUSSION}

The values of the parameters related to the droplet spectrum (VMD, $\% \mathrm{~V}<100 \mu \mathrm{m}$, SPAN) of the spraying systems, in different traveling speeds, are shown in Table 2. It is observed that there were significant differences between technologies for the parameter VMD measured by the particle measurer in all traveling speeds. The VMD values with the rotating nozzle were the lowest compared to other spraying systems, corresponding to the spectrum range of very fine droplets (ASABE, 2009), presenting VMD values of less than $145 \mu \mathrm{m}$ (Table 2). The VMD values with GA air induction model were higher compared to the flat spray model AXI at speeds 2, 3, 4 (12, 15, 25 $\mathrm{km} \mathrm{h}^{-1}$ ). For the latter two tip models, there is a production of fine droplets of 165 to $195 \mu \mathrm{m}$. These results differ from what was indicated by the speed controller of the rotating nozzle and by the catalogs of the hydraulic tips manufacturers, which were adjusted to produce medium size droplets.

For the parameter $\% \mathrm{~V}<100 \mu \mathrm{m}$, higher values were found with the rotating nozzles, while the treatments that used hydraulic tips with air induction had lower values. According to MILLER (2003), droplets smaller than $100 \mu \mathrm{m}$ are more frequently found in samples derived from field studies. Therefore, it is considered that the highest percentage of droplets with a diameter smaller than $100 \mu \mathrm{m}$, found with centrifugal power tip, may result in higher losses for the liquid volume drift, especially when sprayings are held in harsh conditions.

Regarding the relative amplitude of the droplets spectrum (SPAN), the lowest values were observed with the rotary nozzle (TT), being in the range of 0.89 to 1.00 . With the hydraulic tips, the values found were higher than those obtained with the rotating nozzle, especially for the tip with air induction (GA), which showed a value of up to 2.10 in speed $4\left(25 \mathrm{~km} \mathrm{~h}^{-1}\right)$. These results indicate there is greater unevenness of the droplet spectrum produced in sprays with hydraulic tips, when subjected to the speed of $25 \mathrm{~km} \mathrm{~h}^{-1}$.

The effect of the change in operating conditions with increasing traveling speed and the change in the combination of the rotating nozzle resulted in an increase in the droplet size in this system, observed in the VMD increase and reduction $\% \mathrm{~V}<100 \mu \mathrm{m}$. On the other hand, the increase in traveling speed and changing of tips resulted in a significant increase in the heterogeneity of the droplet spectrum produced by the hydraulic tips (GA and AXI). As observed by CUNHA et al. 
(2007), these findings may be the consequence of the increase in the nominal flow and the orifice size.

TABLE 2. Spectrum of spray droplets with different technical and operational conditions in traveling speed.

\begin{tabular}{|c|c|c|c|c|c|}
\hline \multirow{2}{*}{ Technology $(\mathrm{T})$} & \multicolumn{4}{|c|}{ Speed $(\mathrm{S})$} & \\
\hline & 1 & 2 & 3 & 4 & \\
\hline \multirow[b]{2}{*}{${ }^{(1)} \mathrm{TT}$} & \multicolumn{4}{|c|}{ 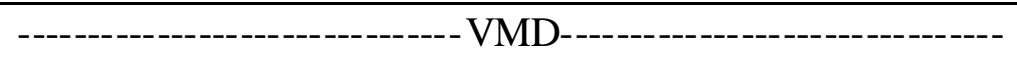 } & $\mathrm{CS} \%=4.90$ \\
\hline & $102.85 \mathrm{bB}$ & $107.24 \mathrm{bC}$ & $114.71 \mathrm{abC}$ & $125.00 \mathrm{aC}$ & $\mathrm{F}_{\mathrm{T}}=380.94 * *$ \\
\hline${ }^{(2)} \mathrm{AXI}$ & $164.84 \mathrm{aA}$ & $167.99 \mathrm{aB}$ & $150.14 \mathrm{bB}$ & $165.48 \mathrm{aB}$ & $\mathrm{F}_{\mathrm{S}}=12.87 * *$ \\
\hline \multirow[t]{2}{*}{${ }^{(2)} \mathrm{GA}$} & $160.71 \mathrm{bA}$ & $188.85 \mathrm{aA}$ & 190.86 aA & $194.00 \mathrm{aA}$ & $\mathrm{F}_{\mathrm{TxS}}=7.759 * *$ \\
\hline & \multicolumn{4}{|c|}{ 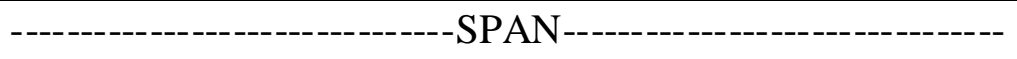 } & $\mathrm{CS} \%=5.52$ \\
\hline TT & $0.91 \mathrm{aC}$ & $0.91 \mathrm{aC}$ & $0.89 \mathrm{aC}$ & $1.00 \mathrm{aB}$ & $\mathrm{F}_{\mathrm{T}}=599.05 * *$ \\
\hline AXI & $1.59 \mathrm{bB}$ & $1.59 \mathrm{bB}$ & $1.57 \mathrm{bB}$ & $2.00 \mathrm{aA}$ & $\mathrm{F}_{\mathrm{S}}=33.01 * *$ \\
\hline \multirow[t]{2}{*}{ GA } & $1.73 \mathrm{cA}$ & $1.79 \mathrm{bcA}$ & $1.90 \mathrm{bA}$ & $2.10 \mathrm{aA}$ & $\mathrm{F}_{\mathrm{VxT}}=4.93 * *$ \\
\hline & \multicolumn{4}{|c|}{ 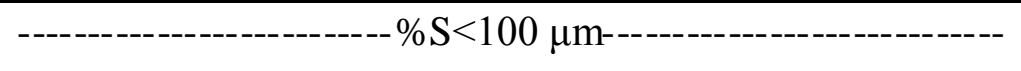 } & $\mathrm{C}_{\mathrm{S}} \%=11.25$ \\
\hline $\mathrm{TT}$ & $46.59 \mathrm{aA}$ & $41.97 \mathrm{aA}$ & $34.70 \mathrm{bA}$ & $28.76 \mathrm{cA}$ & $\mathrm{F}_{\mathrm{T}}=192.01 * *$ \\
\hline AXI & $22.06 \mathrm{abB}$ & $18.67 \mathrm{bB}$ & $25.23 \mathrm{aB}$ & $24.33 \mathrm{aA}$ & $\mathrm{F}_{\mathrm{S}}=11.30 * *$ \\
\hline GA & $22.61 \mathrm{aB}$ & $16.95 \mathrm{bB}$ & $16.83 \mathrm{bC}$ & $17.75 \mathrm{abB}$ & $\mathrm{F}_{\mathrm{SxT}}=12.08 * *$ \\
\hline
\end{tabular}

${ }^{(\mathrm{T})} \mathrm{TT}$ - rotary disk atomizer. ${ }^{(2)} \mathrm{AXI}$ and GA - hydraulic tips. Means followed by the same letter, lowercase in rows and uppercase in columns, do not differ by the Tukey test $(\mathrm{p}>0.05)$. ** Significant $(\mathrm{p}<0.01)$.

\section{Spraying deposits - Expe riment I}

At this stage, plants had a mean height of $0.79 \mathrm{~m}$ and LAI equal to 3.33. The spray deposits on the targets set in the cotton plant apex, adaxial leaf surfaces, were higher in treatments with hydraulic power tips AXI and GA (Table 3). At the apex of the plant leaf, abaxial surface, and at the base of the plant in both leaf surfaces, the use of centrifugal tips provided deposits on average 4.59 times higher than those obtained with hydraulic tips. According to DEBORTOLI et al. (2012) the highest amounts of deposits obtained from the lower parts of the crop canopy indicate potential advantages for use of the rotating nozzle in the control of biological targets located therein.

Similarly to what was found by CUNHA et al. (2011) and BAYER et al. (2012), spray droplet penetration into the crop canopy was favored by the production of drops of smaller VMD. This is probably because the fine droplets are lighter and show greater suspension time, favoring wind interception under less exposed surfaces of the plant. In addition, the angle at which these drop lets are launched with the rotation system may also have contributed to the increased penetration under the crop canopy. 
TABLE 3. Effect of application technology on the spraying deposit $\left(\mu \mathrm{g} \mathrm{cm}^{-2}\right)$ in the adaxial and abaxial surfaces of leaves at the cotton plant apex and base, at 74 days after sowing.

\begin{tabular}{|c|c|c|c|c|c|c|}
\hline \multirow{4}{*}{$\begin{array}{l}\text { Speed } \\
\text { (S) }\end{array}$} & \multicolumn{6}{|c|}{ Technology $(\mathrm{T})$} \\
\hline & $\overline{\mathrm{TT}}$ & AXI & GA & TT & AXI & GA \\
\hline & \multicolumn{3}{|c|}{$\overline{\operatorname{Deposit}\left(\mu \mathrm{g} \mathrm{cm}^{-2}\right)}$} & \multicolumn{3}{|c|}{$\overline{\operatorname{Deposit}\left(\mu \mathrm{g} \mathrm{cm}^{-2}\right)}$} \\
\hline & \multicolumn{3}{|c|}{ Apex/Adaxial } & \multicolumn{3}{|c|}{ Apex/Abaxial } \\
\hline 1 & $0.6930 \mathrm{bAB}$ & $1.1302 \mathrm{aA}$ & $1.2450 \mathrm{aA}$ & $0.5284 \mathrm{aB}$ & $0.0991 \mathrm{cAB}$ & $0.1679 \mathrm{bAB}$ \\
\hline 2 & $0.6041 \mathrm{bB}$ & $1.1528 \mathrm{aA}$ & $1.0768 \mathrm{aAB}$ & $0.5990 \mathrm{aA}$ & $0.0905 \mathrm{bB}$ & $0.1381 \mathrm{bB}$ \\
\hline 3 & $0.7686 \mathrm{bAB}$ & $1.0257 \mathrm{aA}$ & $0.9828 \mathrm{aB}$ & $0.5591 \mathrm{aAB}$ & $0.1509 \mathrm{bA}$ & $0.2028 \mathrm{bA}$ \\
\hline \multirow[t]{3}{*}{4} & $0.8852 \mathrm{aA}$ & $1.0393 \mathrm{aA}$ & $0.8765 \mathrm{aB}$ & $0.3860 \mathrm{aC}$ & $0.1111 \mathrm{bAB}$ & $0.1395 \mathrm{bB}$ \\
\hline & \multicolumn{3}{|c|}{$\begin{array}{l}\mathrm{CS} \%=12.16 ; \mathrm{F}_{\mathrm{T}}=43.00^{* *} \\
\mathrm{~F}_{\mathrm{S}}=1.77^{\mathrm{ns}} ; \mathrm{F}_{\mathrm{TXS}}=5.42^{* *} ; \mathrm{F}_{\text {block }}=1.41^{\mathrm{ns}}\end{array}$} & \multicolumn{3}{|c|}{$\begin{array}{l}\mathrm{CS} \%=11.85 ; \mathrm{F}_{\mathrm{T}}=121.73^{* *} \\
\mathrm{~F}_{\mathrm{V}}=18.09^{* *} ; \mathrm{F}_{\mathrm{TXS}}=11.78^{* *} ; \mathrm{F}_{\text {block }}=0.08^{\mathrm{ns}}\end{array}$} \\
\hline & \multicolumn{3}{|l|}{ Base/Adaxial } & \multicolumn{3}{|l|}{ Base/Abaxial } \\
\hline 1 & $0.5219 \mathrm{aA}$ & $0.1804 \mathrm{bA}$ & $0.2186 \mathrm{bA}$ & $0.4073 \mathrm{aA}$ & $0.0738 \mathrm{cA}$ & $0.1588 \mathrm{bAB}$ \\
\hline 2 & $0.3298 \mathrm{aB}$ & $0.1455 \mathrm{bA}$ & $0.1984 \mathrm{bA}$ & $0.2306 \mathrm{aB}$ & $0.0873 \mathrm{bA}$ & $0.1164 \mathrm{bB}$ \\
\hline 3 & $0.2930 \mathrm{aB}$ & $0.1260 \mathrm{bA}$ & $0.1079 \mathrm{bB}$ & $0.2146 \mathrm{aB}$ & $0.0836 \mathrm{bA}$ & $0.2214 \mathrm{aA}$ \\
\hline \multirow[t]{3}{*}{4} & $0.3176 \mathrm{aB}$ & $0.1577 \mathrm{bA}$ & $0.0630 \mathrm{cB}$ & $0.2691 \mathrm{aB}$ & $0.1182 \mathrm{bA}$ & $0.1226 \mathrm{bB}$ \\
\hline & \multicolumn{3}{|c|}{$\mathrm{CS} \%=20.91 ; \mathrm{F}_{\mathrm{T}}=115.804 * *$} & \multicolumn{3}{|c|}{$\mathrm{CS} \%=19.95 ; \mathrm{F}_{\mathrm{T}}=121.73^{* *}$} \\
\hline & \multicolumn{3}{|c|}{$\mathrm{FS}=20.84^{* *} ; \mathrm{F}_{\mathrm{Tx}}=5.47 * * ; \mathrm{F}_{\text {block }}=0.78^{\mathrm{ns}}$} & \multicolumn{3}{|c|}{$\mathrm{F}_{\mathrm{S}}=7.87^{* *} ; \mathrm{F}_{\mathrm{TxS}}=13.02^{* *} ; \mathrm{F}_{\text {block }}=1.40^{\mathrm{ns}}$} \\
\hline
\end{tabular}

${ }^{\mathrm{T}} \mathrm{TT}$ - rotary disc atomizer. ${ }^{2} \mathrm{AXI}$ and GA - hydraulic tips. Means followed by the same letter, lowercase in rows and uppercase in columns, do not differ by the Tukey test $(\mathrm{p}>0.05) .{ }^{\mathrm{ns}}$ Not significant $((\mathrm{p}<0.01)$; ** Significant $(\mathrm{p}<0.01)$.

Regarding the travel speeds and changes in operational settings on the marker deposit for different application systems, it was found that speed $4\left(12 \mathrm{~km} \mathrm{~h}^{-1}\right)$ provided greater marker deposits with the rotating nozzle at the plant apex, adaxial leaf surface. In the other positions, this speed provided smaller marker deposit value (Table 3). These results are probably due to the increased flow rate and the droplet size increase generated by the rotating nozzle on the travel speed of $25 \mathrm{~km} \mathrm{~h}^{-1}$ (Table 2).

For the hydraulic tip model GA, the greatest deposit levels were found in speed $1\left(12 \mathrm{~km} \mathrm{~h}^{-1}\right)$ at the plant apex, adaxial leaf surface. For this technology there was a significant reduction of the marker deposit at the plant apex and base, on the adaxial surface when submitted to travel speeds 3 and 4 (18 and $\left.25 \mathrm{~km} \mathrm{~h}^{-1}\right)$. Possibly, these results are associated with increased heterogeneity of the droplets spectrum (SPAN greater values) obtained at velocities of 18 and $25 \mathrm{~km} \mathrm{~h}^{-1}$ (Table 2). Thus, the advantages pointed out by the GA tip manufacturer due to the presence of tilted jet and air induction have not been accomplished in the treatments with higher speeds.

Regarding the flat jet nozzle model AXI, there were only slight differences in deposits obtained in the different travel speeds and it can thus be inferred that for this tip model, the travel speeds did not influence the deposit levels for this pulverization system.

\section{Spraying deposit - Experiment II}

Spraying deposits at the apex, middle part and base of the plants, at 117 DAS, are shown in Table 4. In this time of evaluation, the average size of plants was $1.04 \mathrm{~m}$ and LAI was 4.95. It can be seen that the differences between treatments observed for spraying deposit at this development stage were similar at 74 DAS, with the rotating nozzle presenting lower deposit values below the adaxial surface of the leaf at the plant apex and higher on the abaxial surface of the apex and on both surfaces in other parts of the plant. On the other hand, the means of marker deposits obtained with the hydraulic tips were very similar in all positions evaluated. Marker deposits found in the plant apex, adaxial surface of the leaves, were the ones closer to the values found at 74 DAS. In other parts, deposits were relatively lower than those obtained in the first evaluation were. These 
results show that the spray penetration is favored in the early development stages of the plant, when the canopy is not fully closed (IAF 3.33 at 74 DAS).

These results were similar to those found by ZHU et al. (2004) evaluating the spraying deposits at different development stages of the peanut crop. These authors found that there was a decreasing linear relation between the deposit averages obtained and the crop development cycle. This statement was confirmed for the four different models of spray tips tested, including standard flat jet tips and with air induction.

In relation to the traveling speed, significant differences were found for marker deposit, especially at the plant apex, adaxial leaf surface, for the hydraulic tips AXI and GA. In this position the larger deposit values were obtained with the flat jet tip AXI, when operated at speeds 1, 2 and 3 $\left(12,15\right.$ and $18 \mathrm{~km} \mathrm{~h}^{-1}$ ), while for the air induction tip GA, the traveling speed of $12 \mathrm{~km} \mathrm{~h}^{-1}$, provided greater deposit levels. In the other plant assessment positions, there were no differences in deposit values at different speeds.

These results were similar to those found in the first evaluation period (74 DAS), being justified by drops of larger diameter (VMD) produced by rotating nozzles accumulating under more exposed plant parts, besides the greater heterogeneity of the drops from hydraulic tips, resulting in higher drift losses and/or running, when at higher speeds. However, at DAS 117, the influence of the traveling speed factor was less significant.

TABLE 4. Effect of the application technology and traveling speed over the spraying deposit on the adaxial and abaxial leaf surfaces, at the apex and basis of cotton plant, at 117 days after sowing.

\begin{tabular}{|c|c|c|c|c|c|c|}
\hline \multirow{4}{*}{$\begin{array}{l}\text { Speed } \\
(\mathrm{S})\end{array}$} & \multicolumn{6}{|c|}{ Technology $(\mathrm{T})$} \\
\hline & $\mathrm{TT}$ & AXI & GA & TT & AXI & GA \\
\hline & \multicolumn{3}{|c|}{$\overline{\text { Deposit }\left(\mu \mathrm{g} \mathrm{cm}^{-2}\right)}$} & \multicolumn{3}{|c|}{$\overline{\operatorname{Deposit}\left(\mu \mathrm{g} \mathrm{cm}^{-2}\right)}$} \\
\hline & \multicolumn{3}{|c|}{ Apex/Adaxial } & \multicolumn{3}{|c|}{ Apex/Abaxial } \\
\hline$\overline{1}$ & $0.6727 \mathrm{bA}$ & $0.9967 \mathrm{aAB}$ & $1.1103 \mathrm{aA}$ & $0.3237 \mathrm{aB}$ & $0.0288 \mathrm{bA}$ & $0.0338 \mathrm{bA}$ \\
\hline 2 & $0.5892 \mathrm{bA}$ & $1.0960 \mathrm{aA}$ & $0.9634 \mathrm{aAB}$ & $0.5275 \mathrm{aA}$ & $0.0529 \mathrm{bA}$ & $0.0597 \mathrm{bA}$ \\
\hline 3 & $0.7286 \mathrm{aA}$ & $0.9391 \mathrm{aAB}$ & $0.8356 \mathrm{aB}$ & $0.5376 \mathrm{aA}$ & $0.0727 \mathrm{bA}$ & $0.0422 \mathrm{bA}$ \\
\hline \multirow[t]{3}{*}{4} & $0.7936 \mathrm{aA}$ & $0.7726 \mathrm{aB}$ & $0.8299 \mathrm{aB}$ & $0.3675 \mathrm{aB}$ & $0.0512 \mathrm{bA}$ & $0.0467 \mathrm{bA}$ \\
\hline & \multicolumn{3}{|c|}{$\begin{array}{l}\mathrm{CV} \%=14.59 ; \mathrm{F}_{\mathrm{T}}=20.70^{* *} \\
\mathrm{~F}_{\mathrm{S}}=2.38^{\mathrm{ns}} ; \mathrm{F}_{\mathrm{TXS}}=4.31^{* *} ; \mathrm{F}_{\text {block }}=0.22^{\mathrm{ns}}\end{array}$} & \multirow{2}{*}{\multicolumn{3}{|c|}{$\begin{array}{l}\mathrm{CV} \%=14.98 ; \mathrm{F}_{\mathrm{T}}=1135.62 * * \\
\mathrm{~F}_{\mathrm{S}}=32.14 * * ; \mathrm{F}_{\mathrm{TXS}}=18.62 * * ; \mathrm{F}_{\text {block }}=1.29^{\mathrm{ns}}\end{array}$}} \\
\hline & \multicolumn{3}{|c|}{ Average/ Adaxial } & & & \\
\hline 1 & $0.2379 \mathrm{aB}$ & $0.1027 \mathrm{bA}$ & $0.0911 \mathrm{bA}$ & $0.2742 \mathrm{aB}$ & $0.0231 \mathrm{bA}$ & $0.0119 \mathrm{bA}$ \\
\hline 2 & $0.4291 \mathrm{aA}$ & $0.1023 \mathrm{bA}$ & $0.0568 \mathrm{bA}$ & $0.3348 \mathrm{aA}$ & $0.0262 \mathrm{bA}$ & $0.0177 \mathrm{bA}$ \\
\hline 3 & $0.2766 \mathrm{aB}$ & $0.1411 \mathrm{bA}$ & $0.1057 \mathrm{bA}$ & $0.3163 \mathrm{aAB}$ & $0.0321 \mathrm{bA}$ & $0.0396 \mathrm{bA}$ \\
\hline \multirow[t]{3}{*}{4} & $0.2554 \mathrm{aB}$ & $0.0735 \mathrm{bA}$ & $0.1112 \mathrm{bA}$ & 0.3068 a $\mathrm{AB}$ & $0.0188 \mathrm{bA}$ & $0.0190 \mathrm{bA}$ \\
\hline & \multicolumn{3}{|c|}{$\overline{\mathrm{CV} \%=21.56 ; \mathrm{F}_{\mathrm{T}}=171.61 * *}$} & \multicolumn{3}{|c|}{$\begin{array}{l}\overline{\mathrm{CV}} \%=21.99 ; \mathrm{F}_{\mathrm{T}}=637.11^{* *} \\
\mathrm{~F}_{\mathrm{V}}=2.53^{\text {ns }} ; \mathrm{F}_{\mathrm{TXV}}=1.16^{\mathrm{ns}} ; \mathrm{F}_{\text {plot }}=0.38^{\mathrm{ns}}\end{array}$} \\
\hline & \multicolumn{3}{|c|}{ Base/Adaxial } & \multicolumn{3}{|c|}{ Base/Abaxial } \\
\hline 1 & $0.2306 \mathrm{aA}$ & $0.0278 \mathrm{bB}$ & $0.0349 \mathrm{bA}$ & $0.2216 \mathrm{aA}$ & $0.0221 \mathrm{bA}$ & $0.0218 \mathrm{bA}$ \\
\hline 2 & $0.2325 \mathrm{aA}$ & $0.0481 \mathrm{bAB}$ & $0.0506 \mathrm{bA}$ & $0.2330 \mathrm{aA}$ & $0.0398 \mathrm{bA}$ & $0.0297 \mathrm{bA}$ \\
\hline 3 & $0.2614 \mathrm{aA}$ & $0.0830 \mathrm{bA}$ & $0.0350 \mathrm{cA}$ & $0.2179 \mathrm{aA}$ & $0.0344 \mathrm{bA}$ & $0.0115 \mathrm{bA}$ \\
\hline \multirow[t]{2}{*}{4} & $0.2456 \mathrm{aA}$ & $0.0518 \mathrm{bAB}$ & $0.0378 \mathrm{bA}$ & $0.2243 \mathrm{aA}$ & $0.0227 \mathrm{bA}$ & $0.0146 \mathrm{bA}$ \\
\hline & \multicolumn{3}{|c|}{$\mathrm{CS} \%=22.12 ; \mathrm{F}_{\mathrm{T}}=338.86^{* *}$} & \multicolumn{3}{|c|}{$\begin{array}{l}\overline{C S} \%=20.98 ; F_{T}=583.09^{* *} \\
F_{S}=1.39^{\text {ns. }} ; F_{T X S}=0.3^{\text {ns }} ; F_{\text {block }}=2.07^{\text {ns }}\end{array}$} \\
\hline
\end{tabular}

Means followed by the same letter on the row do not differ by the Tukey test ( $\mathrm{p}>0.05)$. ** Significant at 0.01 . 
Regarding the uniformity of marker deposits distribution along the plan profile, it may be inferred that the best results were obtained with the rotating nozzle when it was operated at speed 1 $\left(12 \mathrm{~km} \mathrm{~h}^{-1}\right)$, having greater deposit distribution uniformity on the leaf surfaces evaluated at 74 DAS (Figure 1A).

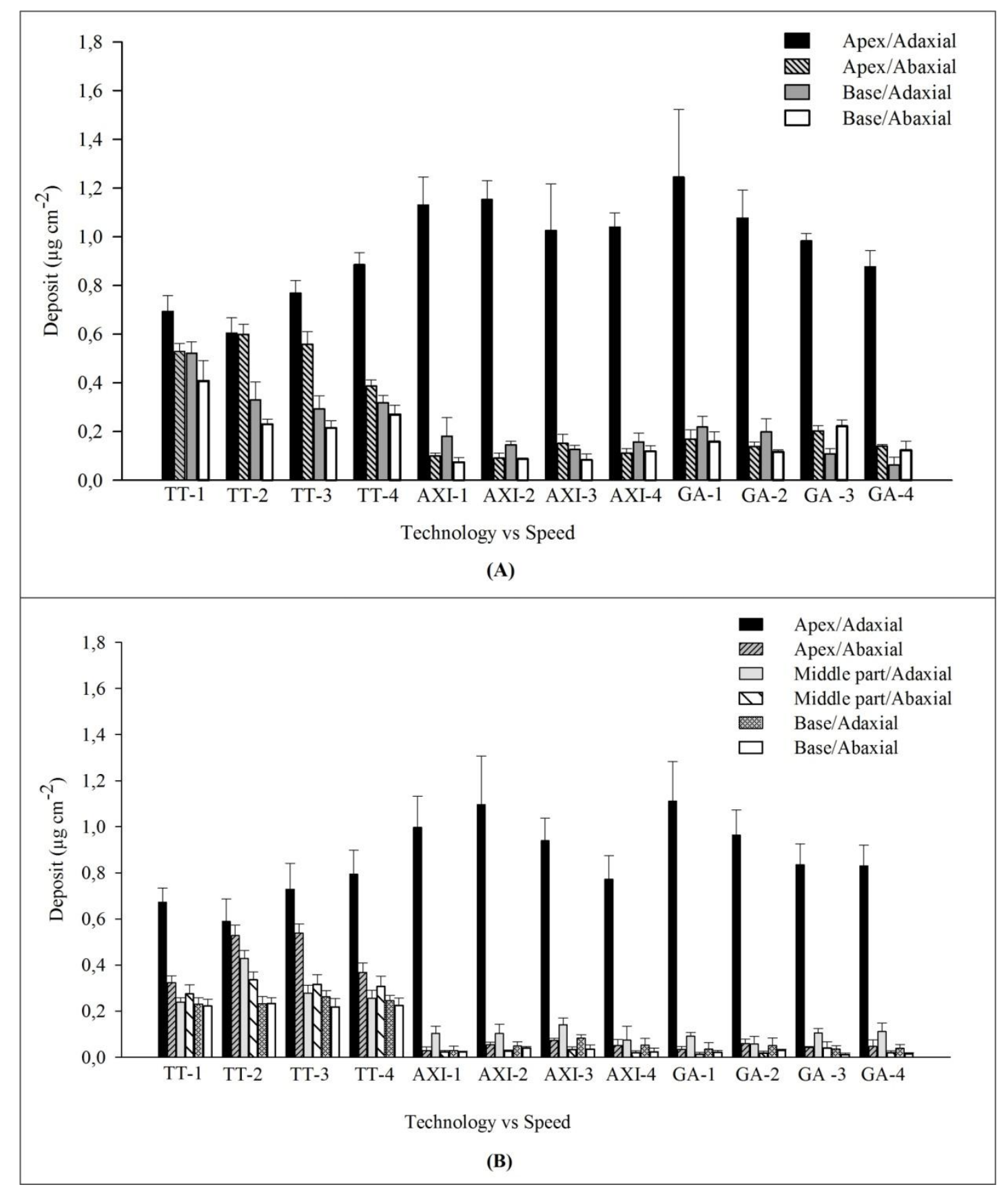

FIGURE 1. Uniformity of spraying deposits along the cotton plant profile, at 74 (A) and 117 days after sowing (B), using different spraying technologies and sprayer traveling speeds.

Importantly, at this speed condition, the rotating nozzle has lower VMD and a larger percentage of droplets smaller than $100 \mu \mathrm{m}$ (Figure 1) which, despite being more prone to drift, facilitates the penetration of the crop canopy, increasing the deposit levels in parts of lower exposure to sprayings.

At 117 DAS, the deposit distribution along the plant profile was less affected in the treatments with higher speeds when compared to the first evaluation. At this stage, the culture showed greater restriction to the drop penetration due to higher LAI, and deposit levels obtained at both speeds were similar (Figure 1B). 
Greater deposit unevenness was obtained with hydraulic tips (AXI and GA), as shown in Figure 1. As evidenced by ZHU et al. (2004), there are greater penetration difficulties of droplets in the crop canopy with the development of the plant and its LAI. This condition indicates that the chemical control of the culture's internal targets may be less efficient in later development stages of cotton, with the need for adoption of new production technologies and application of crop protection products.

\section{CONCLUSIONS}

Changes in the operational settings required for increased traveling speed negatively influence the droplet spectrum and its homogeneity, affecting the vertical distribution of the spraying deposits on cotton plants.

The rotating nozzle provides greater deposit penetration and uniformity on the cotton plant canopy, even when the culture is in full development and it can serve as an important tool for the control of biological targets located in the parts of the plant which are of difficult access for the spraying droplets.

\section{REFERENCES}

AGRIANUAL. Algodão: algodão - cus to de produção. In: AGRIANUAL: Anuário da agricultura brasileira. São Paulo: FNP, 2013. p. 145-156.

ASABE - AMERICAN SOCIETY OF AGRICULTURAL AND BIOLOGICAL ENGINEERS (Ed.). D roplet chart / selection guide. Virginia: Asabe, 2009. 2 p.

BAYER, T.; ARRUÉ, A.; COSTA, I. F. D.; LENZ, G.; CORADINI, C.; SARI, B. G.; PES, M. P. Aplicação aérea de fungicidas na cultura do arroz irrigado com diferentes bicos de pulverização. Ciência Rural, Santa Maria, v. 42, n. 12, p.2185-2191, dez. 2012.

BOLLER, W.; RAETANO, C. G. Bicos e pontas de pulverização de energia hidráulica. In: ANTUNIASSI, U. R.; BOLLER, W. Tecnologia de aplicação para culturas anuais. Passo Fundo: Aldeia Norte; Botucatu: FEPAF, 2011. p. 51-82.

CHRISTOVAM, R. S.; RAETANO, C. G.; PRADO, E. P.; DAL POGETTO, M. H. F. A.; AGUIAR JÚNIOR, H. O.; GIMENES, M. J.; SERRA, M. E. Air-assistance and low volume application to control of asian rust on soybean crop. Journal of Plant Protection Research, Poznán, v.50, n.3, p.354-359, 2010.

CUNHA, J. P. A. R.; TEIXEIRA, M. M.; FERNANDES, H. C. Avaliação do espectro de gotas de pontas de pulverização hidráulicas utilizando a técnica da difração do raio laser. Engenharia Agrícola, Jaboticabal, v.27, p.10-15, jan. 2007. Número especial.

CUNHA, J. P. A. R.; FARNESE, A. C.; OLIVET, J. J.; VILlLALBA, J. Deposição de calda pulverizada na cultura da soja promovida pela aplicação aérea e terrestre. Engenharia Agrícola, Jaboticabal, v.31, n.2, p.343-351, mar./abr. 2011.

CZEPAK, C.; ALBERNAZ, K. C.; VIVAN, L. M.; GUIMARÃES, H. O.; CARVALHAIS, T. Primeiro regis tro de ocorrência de Helicoverpa armigera (Hübner) (Lepidoptera: Noctuidae) no Brasil. Pesquisa Agropecuária Tropical, Goiânia, v.43, n. 1, p.110-113, jan. 2013.

DEBORTOLI, M. P.; TORMEN, N. R.; BALARDIN, R. S.; FAVERA, D. D.; STEFANELLO, M. T.; PINTO, F. F; UEBEL, J. D. Espectro de gotas de pulverização e controle da ferrugem-asiática-da-soja em cultivares com diferentes arquiteturas de planta. Pesquisa Agropecuá ria B rasileira, Brasília, v.47, n.7, p.920-927, jul. 2012.

DI OLIVEIRA, J. R. G.; FERREIRA, M. C.; ROMÁN, R. A. A. Diferentes diâmetros de gotas e equipamentos para aplicação de inseticida no controle de Pseudoplusia includens. Engenharia Agrícola, Jaboticabal, v.30, n.1, p.92-99, jan./fev. 2010. 
HEIDARY, M.; DOUZALS, J. P.; SINFORT, C.; VALLET, A. Influence of spray characteristic s on potential spray drift of field crop sprayers: A literature review. Crop Protection, Guildford, v.63, p.120-130, 2014.

HYPRO. GuardianAIR spray nozzles. 2015. Disponível em:

<http://www.hypropumps.com/EngineeredProduct_Product_GuardianAIRSprayTips.aspx >. Acesso em: $1^{\underline{o}}$ out. 2015.

JACTO. Es pecificações técnicas da série AXI. 2012. Disponível em:

$<$ http://www.jacto.com.br/pt/produto/detalhes/73/axi>. Aces so em: 1ํㅡㅁ 2014.

MARUR, C. J.; RUANO, O. A reference system for determination of developmental stages of upland cotton. Revista de Oleaginosas e Fibrosas, Campina Grande, v.5, p.313-317, 2001.

MILLER, P. The measurement of spray drift. 2003. Disponível em:

<http://pubs.rsc.org/en/content/articlepdf/2003/po/b311466j>. Acesso em: 23 maio 2014.

SANTOS, W. J. Manejo das pragas do algodão com destaque para o cerrado brasileiro. In: FREIRE, E. C. (Ed.). Algodão no cerrado do B rasil. 2. ed. Brasília: ABRAPA, 2011. p. 403-478.

WOLF, R. E.; DAGGUPATI, N. P. Nozzle type effect on soybean canopy penetration. Applied Engineering In Agriculture, Kansas, v.25, n.1, p.23-30, jan. 2009.

ZHU, H.; DORNER, J. W.; ROWLAND, D. L.; DERKSEN, R. C.; OZKAN, H. E. Spray penetration into peanut canopies with hydraulic nozzle tips. Biosystems Engineering, London, v.87, n.3, p.275-283, 2004. 